\title{
NRXN1 Gene
}

National Cancer Institute

\section{Source}

National Cancer Institute. NRXN1 Gene. NCI Thesaurus. Code C82879.

This gene is involved in cell recognition, cellular adhesion and signal transduction. 